\title{
GAMIFIED TRAINING SESSIONS AS MEANS OF ENHANCING STUDENTS' MOTIVATION IN LEARNING ENGLISH
}

\section{Tsymbal Svitlana}

PhD (Psychology), Associate Professor of the Department of English for Technical and Agrobiological Specialities, National University of Life and Environmental Sciences of Ukraine, Kyiv (Ukraine)

ORCID ID: https://orcid.org/0000-0003-0652-369X

\begin{abstract}
Motivation is one of the vital factors in learning a language, the feelings and excitement offered by extra enthusiasm for students to learn a second language in a better way. For the past twenty years, teaching methods have been developed to enhance the students' motivation with the purpose of improving their language skills. Using games in ESL classroom is one of such methods supplementing the teachinglearning process. In this article, we examined how gamified method of teaching ESL may affect the attitude of university students towards the language and their level of motivation. The study was conducted to 112 freshmen of the National University of Life and Environmental Sciences of Ukraine. The design of this study was quantitative in nature that employed two questionnaires as a measuring instrument. The participants were required to answer all the items of the questionnaires, giving their own perceptions about 1) their experience of learning English and 2) their attitudes toward using games in learning English to boost their learning motivation. The obtained data revealed that using gamified training sessions was mostly successful in enhancing students' motivation in learning English and the majority of students revealed positive attitudes to using games in language learning. Only 6\% of students wrote in the descriptive questions that they did not build confidence and their level of interest in English learning remained low during the training sessions. It is very important that students mentioned that their level of motivation and confidence increased and they felt much more secure and safe. The total percentage of students who revealed increased motivation and confidence after Kahoot-based training sessions was 66\%; 28\% of students remained neutral and $6 \%$ of students wrote in the descriptive questions that they did not build confidence and their level of interest in English learning remained low during the training sessions. The fact that a vast majority of students revealed positive attitudes to using games in language learning suggests that this method could be of use when utilized systematically over the academic year. However, university teachers should try
\end{abstract}


various approaches and strategies to create a supportive learning environment in the classroom where learners feel interested, safe and secure to set and pursue their learning goals. In our further research, we will try to investigate other methods of keeping students motivated and engaged in ESL learning.

Keywords: motivation; ESL teaching/learning; gamified method; training sessions.

\section{INTRODUCTION}

The problem setting. The English language plays an important role in today's communication society which is continuously increasing as the world rapidly moves towards globalization. Learning a second language assists students in gaining achievements in academic areas. It has been proved that learners with higher motivation do better in English, and learners with self-confidence tend to be more successful in learning. For the past twenty years, teaching methods have been developed to enhance the students' motivation and selfconfidence with the purpose of improving their language skills. The contemporary society is constantly changing and developing new technologies. Using games in ESL classroom is one of such methods supplementing the teachinglearning process. Games are fun activities that promote learning motivation, critical thinking, interaction, and problem solving. According to Martinson and Chu, "games are effective tools for learning because they offer students a hypothetical environment in which they can explore alternative decisions without the risk of failure. Thought and action are combined into purposeful behaviour to accomplish a goal. Playing games teaches us how to strategize, to consider alternatives, and to think flexibly" [9, 478]. Games stimulate interactivity and allow the students to work collaboratively as a team towards a common goal. This collaborative effort promotes motivation to succeed and learn from each other. Despite this interest in using online games-based learning, there is a lack of empirical evidence supporting the validity of this approach in the Ukrainian context which makes our study topical.

\section{Analysis of recent studies and publica-}

tions. So far, there have been conducted a great number of domestic and foreign studies related to the issue of using games to enhance students' motivation in ESL learning $[1 ; 2 ; 3 ; 4 ; 7 ; 8]$. For one, C. Ray Graham and Mark M. Walsh in their "Adult Education ESL Teachers Guide" suggest that three ways to keep students motivated enough to come to class are 1) to assure that students feel they are making progress toward their goals, 2) to make sure there is the opportunity for enjoyment in the classroom, and 3) to offer lessons that are relevant to them [5]. Wright, Betteridge and Buckby explore the benefits of using games in the ESL classroom and how they might be used to motivate students [1]. Games are not activities mainly aimed to break the ice between students or diverse from routine activities, but a way of getting the learner to use the language in the natural context. Games provide a constructivist classroom environment where students learn through performance, active 
discovery, from their own mistakes and also from each other which involves extensive cognitive processing. Games can provide intense and meaningful practice of language, then they must be regarded as central to a teacher's repertoire. Aydan Ersoz claims, that "games are highly motivating since they are amusing and at the same time challenging. Furthermore, they employ meaningful and useful language in real contexts. They also encourage and increase cooperation" [3]. The advantages of using games in the classroom are as follows: games are a welcome break from the usual routine of the language class; they are motivating and challenging; learning a language requires a great deal of effort; games help students to make and sustain the effort of learning; games provide language practice in the various skills- speaking, writing, listening and reading; they encourage students to interact and communicate; they create a meaningful context for language use [3]. Thus, games have a potential to boost language learning and make this process more engaging and effective. The reasons for this statement are as follows: games get students involved in their learning; they motivate them; games encourage creative and spontaneous use of language; games introduce a change in formal learning situations; games create a pleasant stress-free and relaxing atmosphere in a language class; games unconsciously promote and practise all four basic language skills, such as listening, reading, speaking and writing; games help the teacher to create contexts in which the language is useful and meaningful; games decrease student's anxiety to speak in front of the other students; they feel less intimidated in this, less formal learning situation; games are student-centred; games can promote collaboration among students; and games can connect to a variety of intelligences [8].

The purpose of this study is to discover whether using gamified training sessions will:

- change ESL students' feelings and attitudes toward learning English, and

- enhance their learning motivation.

\section{RESEARCH METHODS}

In our study we used both theoretical (literature review) and empirical methods (questionnaires) to make it possible to answer the main questions addressed in the present paper. The study was conducted to 112 freshmen (4 groups of students) who had a similar English learning experience. The study was conducted during semester I of the 2017-2018 academic year at the National University of Life and Environmental Sciences of Ukraine. The design of this study was quantitative in nature that is descriptive and inferential as well. Two questionnaires were employed as a measuring instrument. The participants were required to answer all the items of the questionnaires, giving their own perceptions about 1) their experience of learning English and 2) their attitudes toward using games in learning English to boost their learning motivation.

\section{THE RESULTS AND DISCUSSION}


According to the goals of this study, the researcher aims to investigate how games affect students' motivation - a powerful factor in ESL learning.

Motivation is known as a stimulant for achieving a specific target. According to Gardner's theory [4], motivation is a kind of central mental engine or energy-center that includes effort, want or will (cognition) and task-enjoyment (affect). Motivation provides the primary momentum to initiate L2 learning and all the other factors involved in L2 acquisition presuppose motivation to some extent. Without sufficient motivation, even individuals with the most remarkable abilities cannot accomplish long-term goals, and neither are appropriate curricula and good teaching enough on their own to ensure learner achievement.

According to Hussin, Maarof and D'Cruz, "teachers need to find creative ways to teach the language and increase the student's motivation to learn the language and to eventually appreciate the language" [7]. Learning motivation is considered to be a key factor to success in second language acquisition which can develop students' curiosity about learning English. Motivation works as the starting point for learning and supporting the process of foreign language acquisition. In fact, we can say that if there is lack of motivation, no student will be able to continue with the process of achieving language proficiency; on the other hand, high motivation will be useful for learners to attain proper proficiency in the second language, even if their aptitude or learning conditions are not appropriate [2]. Harmer states that motivation is a type of initiative that encourages someone to do things to reach a goal. Furthermore, this is fundamental to succeed in most fields of learning; without such motivation, we will not be able to make the effort to learn. For this reason, it is necessary to understand the role it has when learning a language [6]. The author of this paper suggests that the use of gamified training sessions in ESL learning will show the direct relationship between engaging gamified learning and increased motivation.

Prior to using gamified training sessions, students were given a questionnaire containing 18 questions about their feeling toward the conventional English lessons they used to have at school before entering the university, the teaching method used by teachers, their level of learning motivation and confidence.

The responses to the questionnaire showed that the students generally were neutral in looking forward to English lessons (40\%). The participants' responses revealed that $32 \%$ of students did not feel confident to speak English and $38 \%$ of students get confused to ask questions during the lesson. 41\% (agree) and 18\% (strongly agree) of students thought that it is important to learn English and no one said that English is unimportant. On the questions focusing on the teaching methods, it was revealed that 19\% (strongly agree) and 38\% (agree) liked it 


\section{Students' feelings toward learning English before using gamified training sessions}

\begin{tabular}{|c|c|c|c|c|c|}
\hline Statement & $\begin{array}{l}\text { Strongly } \\
\text { agree }\end{array}$ & $\overline{\text { Agree }}$ & Neutral & Disagree & $\begin{array}{c}\text { Strongly disa- } \\
\text { gree }\end{array}$ \\
\hline $\begin{array}{l}\text { 1. I usually look forward to my English } \\
\text { lesson }\end{array}$ & $9 \%$ & $22 \%$ & $40 \%$ & $25 \%$ & $4 \%$ \\
\hline 2. I think it is important to learn English & $18 \%$ & $41 \%$ & $39 \%$ & $2 \%$ & $0 \%$ \\
\hline $\begin{array}{l}\text { 3. I like doing grammar exercises in the } \\
\text { textbook in order to better learn English }\end{array}$ & $5 \%$ & $6 \%$ & $8 \%$ & $39 \%$ & $42 \%$ \\
\hline $\begin{array}{l}\text { 4. I like working in groups when learning } \\
\text { English }\end{array}$ & $12 \%$ & $16 \%$ & $33 \%$ & $29 \%$ & $10 \%$ \\
\hline $\begin{array}{l}\text { 5.I think that learning English is quite bor- } \\
\text { ing }\end{array}$ & $4 \%$ & $9 \%$ & $26 \%$ & $43 \%$ & $18 \%$ \\
\hline 6. I think English is hard to learn & $9 \%$ & $20 \%$ & $41 \%$ & $18 \%$ & $12 \%$ \\
\hline 7. English is my favourite subject to learn & $13 \%$ & $27 \%$ & $29 \%$ & $13 \%$ & $8 \%$ \\
\hline $\begin{array}{l}\text { 8. I like it when the teacher uses visual } \\
\text { aids, games, a lot of activities to teach } \\
\text { English }\end{array}$ & $19 \%$ & $38 \%$ & $24 \%$ & $18 \%$ & $1 \%$ \\
\hline $\begin{array}{l}\text { 9. I get confused to ask questions during } \\
\text { the lesson }\end{array}$ & $17 \%$ & $35 \%$ & $28 \%$ & $12 \%$ & $8 \%$ \\
\hline $\begin{array}{l}\text { 10. I prefer independent activities rather } \\
\text { than cooperative learning }\end{array}$ & $7 \%$ & $24 \%$ & $32 \%$ & $17 \%$ & $10 \%$ \\
\hline $\begin{array}{l}\text { 11. I do not feel confident to speak English } \\
\text { and it makes me feel worried. }\end{array}$ & $27 \%$ & $32 \%$ & $26 \%$ & $8 \%$ & $7 \%$ \\
\hline $\begin{array}{l}\text { 12. When I miss the lesson, I never ask my } \\
\text { peers for the homework. }\end{array}$ & $4 \%$ & $6 \%$ & $46 \%$ & $23 \%$ & $21 \%$ \\
\hline $\begin{array}{l}\text { 13. I cannot apply the knowledge of Eng- } \\
\text { lish in the real life }\end{array}$ & $19 \%$ & $34 \%$ & $25 \%$ & $18 \%$ & $4 \%$ \\
\hline $\begin{array}{l}14 . \text { I am not satisfied with my } \\
\text { achievements in English }\end{array}$ & $23 \%$ & $30 \%$ & $36 \%$ & $9 \%$ & $2 \%$ \\
\hline $\begin{array}{l}\text { 15. I have little motivation and interest in } \\
\text { learning English }\end{array}$ & $2 \%$ & $5 \%$ & $31 \%$ & $39 \%$ & $13 \%$ \\
\hline $\begin{array}{l}\text { 16. Learning English helps me to com- } \\
\text { municate with natives and surf the Internet }\end{array}$ & $14 \%$ & $23 \%$ & $31 \%$ & $21 \%$ & $11 \%$ \\
\hline $\begin{array}{l}\text { 17. Learning English with the help of ICT } \\
\text { is much more effective than traditional } \\
\text { learning }\end{array}$ & $22 \%$ & $29 \%$ & $36 \%$ & $12 \%$ & $1 \%$ \\
\hline 18. I learn English just to pass the exams & $4 \%$ & $11 \%$ & $28 \%$ & $30 \%$ & $27 \%$ \\
\hline
\end{tabular}

when the teacher uses visual aids, games, a lot of activities to teach English, however, only 27\% of students $(10 \%+17 \%)$ preferred cooperative learning rather than independent activities and $28 \%$ of students $(12 \%+16 \%)$ liked working in groups when learning English. Despite the importance of learning English, 4\% strongly agreed that they learn English just to pass the exams and 2\% had little motivation and interest in learning English. 19\% of students strongly agreed that they could not apply the knowledge of English in the real life and for $14 \%$ and 23\% of respondents learning English was not helpful to establish contacts with natives or surf the Internet.

In order to change students' attitudes 
towards learning English and boost their motivation and confidence we decided to conduct a series of training sessions for students with the help of Kahoot game-based method of teaching ESL.

According to Talak-Kiryk [10], some characteristics of good games are as follows:

They are based on a learning objective.
They require interaction.

Games include everyone [10, p.12-13].

Based on these criteria, we developed a series of gamified training sessions ( 8 in total) to boost students' motivation and confidence in ESL.

The stages were as follows:

Table 2

\section{Stages of Gamified Training Sessions}

\begin{tabular}{|l|l|l|}
\hline Stage & \multicolumn{1}{|c|}{ Name } & \multicolumn{1}{c|}{ Content } \\
\hline Stage 1: & Material Preparation & $\begin{array}{l}\text { The total number of 8 games and quizzes were designed on the topics } \\
\text { (according to the Curriculum for the students of the Automatization } \\
\text { and Computer Integrated Technology Faculty): } \\
\text { Types of energy. } \\
\text { The history of electricity. } \\
\text { Electricity and magnetism. } \\
\text { The nature of magnetism. } \\
\end{array}$ \\
& $\begin{array}{l}\text { Electric current. } \\
\text { Alternating current. } \\
\text { Direct current. } \\
\text { New elements of the Periodic Table. }\end{array}$ \\
\hline Stage 2: & Class Preparation & $\begin{array}{l}\text { Students were asked to bring their smart phones or laptops to the } \\
\text { classroom and explained the procedure of the game and the scoring } \\
\text { rules. }\end{array}$ \\
\hline & Kahoot training sessions \\
& $\begin{array}{l}\text { The games and quizzes designed by the researcher were used to } \\
\text { review the material learned during the practical lessons. Giving } \\
\text { feedback to students. }\end{array}$ \\
\hline
\end{tabular}

They give the player control over his own destiny.

They include doable challenges.

They are fun and interesting, thus motivating.

They are based on reality in order to intrinsically motivate the players to continue to play the game.
At the end of the semester, students were given another questionnaire consisting of 12 optional questions and 2 items of descriptive questions, in order to find out the students' attitudes toward using games in ESL learning and changes it made to their level of motivation and confidence. The results of the questionnaire are presented in Table 2. 


\section{Students' Attitudes toward Learning English after Using Gamified Training Sessions}

\begin{tabular}{|l|l|l|l|l|l|}
\hline \multicolumn{1}{|c|}{ Statement } & $\begin{array}{l}\text { Strongly } \\
\text { agree }\end{array}$ & Agree & Neutral & Disagree & $\begin{array}{l}\text { Strongly } \\
\text { disagree }\end{array}$ \\
\hline $\begin{array}{l}\text { 1. I think using learning games is useful for } \\
\text { both students and teachers }\end{array}$ & $22 \%$ & $25 \%$ & $40 \%$ & $9 \%$ & $4 \%$ \\
\hline $\begin{array}{l}\text { 2. I think learning English should not have } \\
\text { fun as a necessary requirement. }\end{array}$ & $8 \%$ & $14 \%$ & $39 \%$ & $23 \%$ & $16 \%$ \\
\hline $\begin{array}{l}3 . \text { I consider using online games is a waste } \\
\text { of time. }\end{array}$ & $5 \%$ & $6 \%$ & $8 \%$ & $39 \%$ & $42 \%$ \\
\hline $\begin{array}{l}\text { 4. I believe that game based learning in } \\
\text { higher education should be an important } \\
\text { teaching tool }\end{array}$ & $22 \%$ & $26 \%$ & $23 \%$ & $19 \%$ & $10 \%$ \\
\hline $\begin{array}{l}\text { 5. I believe that using games creates a } \\
\text { more motivating learning environment }\end{array}$ & $24 \%$ & $34 \%$ & $36 \%$ & $6 \%$ & $0 \%$ \\
\hline $\begin{array}{l}\text { 6. I felt more relaxed and confident to use } \\
\text { English during the training session }\end{array}$ & $29 \%$ & $33 \%$ & $24 \%$ & $8 \%$ & $6 \%$ \\
\hline $\begin{array}{l}7 . \text { Working as a team helped me to im- } \\
\text { prove my English }\end{array}$ & $13 \%$ & $27 \%$ & $29 \%$ & $13 \%$ & $8 \%$ \\
\hline $\begin{array}{l}\text { 8. I found it to be fun and engaging to learn } \\
\text { English using online games }\end{array}$ & $19 \%$ & $38 \%$ & $24 \%$ & $18 \%$ & $1 \%$ \\
\hline $\begin{array}{l}\text { 9. Comments from my teacher and peers } \\
\text { gave me more confidence to try harder }\end{array}$ & $17 \%$ & $35 \%$ & $32 \%$ & $9 \%$ & $7 \%$ \\
\hline $\begin{array}{l}\text { 10. I feel I learned more vocabulary and } \\
\text { improved my memory during the training } \\
\text { sessions }\end{array}$ & $17 \%$ & $24 \%$ & $32 \%$ & $10 \%$ & $7 \%$ \\
\hline $\begin{array}{l}\text { 11. I was more active and engaged in the } \\
\text { activity during the training sessions }\end{array}$ & $27 \%$ & $32 \%$ & $26 \%$ & $8 \%$ & $7 \%$ \\
\hline $\begin{array}{l}\text { 12. I feel I started speaking more English } \\
\text { at the training sessions }\end{array}$ & $21 \%$ & $23 \%$ & $46 \%$ & $6 \%$ & $4 \%$ \\
\hline
\end{tabular}

The data from Table 3 revealed that using gamified training sessions was successful in enhancing students' confidence and motivation in learning English. 22\% of students strongly agreed and $25 \%$ of students agreed that using online learning games is useful for both students and teachers; $24 \%$ and $35 \%$ of students respectively thought that using online games creates a more motivating learning environment. However, 11\% $(5 \%+6 \%)$ considered using online games to be a waste of time. $8 \%$ and $14 \%$ of students respec- tively, thought that learning English should not have fun as a necessary requirement. Judging from the chart below, the percentage of students who felt positive effect of using gamified training sessions on their ESL learning was quite high.

From the descriptive questions about what students liked best about using Kahoot in teaching/learning English, most of the students wrote they liked the engaging and cooperative atmosphere and wanted such games to be used often during English lessons. They also wrote that 


\begin{tabular}{|c|c|c|}
\hline Statement & $\begin{array}{c}\text { Strongly } \\
\text { agree }\end{array}$ & Agree \\
\hline Q10: I feel I learned more vocabulary and improved my memory during the training sessions & 0.17 & 0.24 \\
\hline Q11: I was more active and engaged in the activity during the training sessions & 0.27 & 0.32 \\
\hline Q12: I feel I started speaking more English at the training sessions & 0.21 & 0.23 \\
\hline Q6: I felt more relaxed and confident to use English during the training session & 0.29 & 0.33 \\
\hline Q7: Working as a team helped me to improve my English & 0.13 & 0.27 \\
\hline Q8: I found it to be fun and engaging to learn English using online games & 0.19 & 0.38 \\
\hline Q9: Comments from my teacher and peers gave me more confidence to try harder & 0.17 & 0.35 \\
\hline
\end{tabular}

Chart 1. Percentage of students who felt a positive effect of using gamified training sessions on their ESL learning

it gave them challenge to compete with other students and made them relaxed. Also, students mentioned that their level of motivation and confidence increased and they felt much more secure and safe. The total percentage of students who revealed increased motivation and confidence after Kahoot-based training sessions was $66 \% ; 28 \%$ of students remained neutral and $6 \%$ of students wrote in the descriptive questions that they did not build confidence and their level of interest in English learning remained low during the training sessions (see Chart 2).

\section{CONCLUSIONS AND PROSPECTS}

\section{FOR FURTHER RESEARCH}

Effective ESL teaching/learning has always been one of the most important interest areas for researchers, educators-practitioners. This paper contributes to the discussion on how the game-based method of teaching ESL may affect the attitude of university students towards

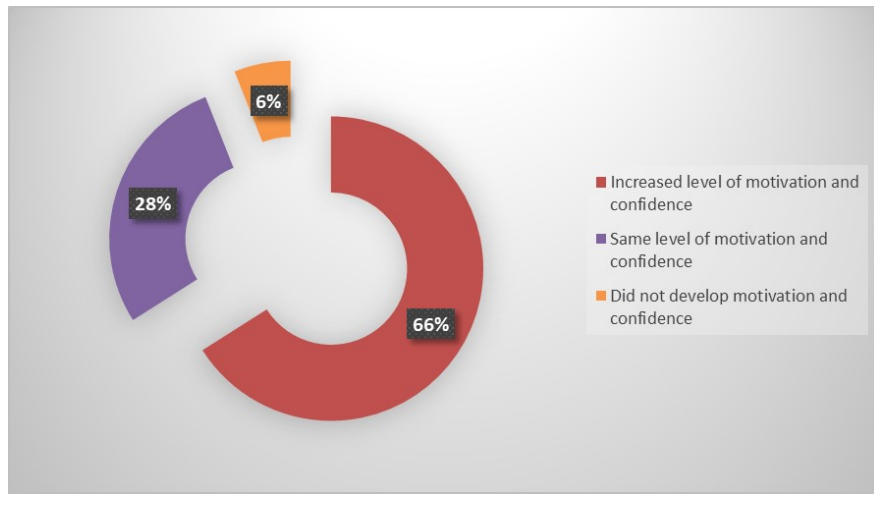

Chart 2. Distribution of students' answers to the descriptive questions as to their motivation and confidence after Kahoot-based training sessions

the language and their level of motivation.

The obtained data revealed that using gamified training sessions was successful in enhancing students' confidence and motivation in learning English. Only 6\% of students wrote in the descriptive questions that they did not build confidence and their level of interest in English learning remained low during the training sessions. 
The fact that a vast majority of students revealed positive attitudes to using games in language learning suggests that this method could be of use when utilized systematically over the academic year. However, 11\% considered using online games to be a waste of time and $22 \%$ of students thought that learning English should not have fun as a necessary requirement. It means, therefore, that an essential part of the teacher's role is to try various approaches and strategies to create a supportive learning environment in the classroom where learners feel interested, safe and secure to set and pursue their learning goals. In our further research, we will try to investigate other methods of keeping students motivated and engaged in ESL learning.

\section{References:}

1. Betteridge W.D., Buckby M. Games for Language Learning // https://books.google.co.uk/books/about/ Games_for_Language_Learning.html? $\mathrm{id}=$ eRgwnQAACAAJ\&redir_esc $=\mathrm{y}$

2. Cheng H., Dörnyei $Z$. The use of motivational strategies in language instruction: The case of EFL teaching in Taiwan / H. Cheng, Z. Dörnyei // International Journal of Innovation in Language Learning and Teaching. - 220. - 1(1). P. 153-174.

3. Ersoz A. Six Games for the EFL/ESL Classroom / Ersoz A. The Internet TESL Journal. - 2000. - Vol. VI, No. 6.

4. Gardner R.C. Motivation and Second Language Acquisition: The Socio-Educational Model / R.C. Gardner //http:// www.tesl-ej.org/wordpress/issues/volume16/ej62/ej62r2/ (in English).

5. Graham C. Ray, Walsh Mark M. Adult Education ESL Teacher's Guide [microform] // http://www.eric.ed.gov/
contentdelivery/servlet/ERICServlet?accno=ED260295

6. Harmer $J$. The practice of English language teaching: Describing learners / J. Harmer. - Harlow: Pearson Education. -2002 .

7. Hussin S. Sustaining an interest in learning English and increasing the motivation to learn English: an enrichment program / S. Hussin, N. Maarof, J. D’Cruz // http:// iteslj.org/Techniques/Hussin-Motivation/

8. Klimova B.F. Games in the Teaching of English / B.F. Klimova // https://ac.els-cdn.com/S1877042815025720/1s2.0-S1877042815025720-main.pdf?_tid=5adc1baa-12444569-a14e-

641812271f24\&acdnat $=1534962346 \_3 c b 11$ f6d854c2cc305

$278 \mathrm{e} 7 \mathrm{f} 18$ caebca

9. Martinson B., Chu Sauman. Impact of Learning Style on Achievement When Using Course Content Delivered Via a Game-based Learning Object / B. Martinson, Sauman Chu. // https://experts.umn.edu/en/publications/impact-oflearning-style-on-achievement-when-using-course-content 10. Talak-Kiryk A. Using Games In A Foreign Language Classroom / A. Talak-Kiryk // MA TESOL Collection. 2010. - N 484.

11. Yudintseva A. Game-Enhanced Second Language Vocabulary Acquisition Strategies: A Systematic Review / A. Yudintseva //Open Journal of Social Sciences. - 2015. N3. - P. 101-109.

\section{Цимбал Світлана}

Кандидат психологічних наук, дочент, дочент кафедри англійської мови для технічних та агробіологічних спеціальностей, Начіональний університет біоресурсів $i$ природокористування Украӥни, м. Київ (Украӥна)

\section{ІГРОВІ ТРЕНІНГИ У ПІДВИЩЕННІ МОТИВАЦІЇ ЩОДО ВИВЧЕННЯ АНГЛІЙСЬКОЇ МОВИ}

Анотація. Мотивація є одним із надзвичайно важливих чинників у вивченні мови, що додає студентам ентузіазму. Протягом останніх двадцяти років були розроблені мето- 
дики навчання, спрямовані на підвищення мотивації студентів 3 метою покращення їхніх мовленнєвих навичок. Використання ігор в аудиторії є одним з таких методів, що доповнюють процес навчання. У цій статті ми розглянули, як ігровий метод викладання англійської мови спеціального вжитку може вплинути на ставлення студентів до мови та рівня їхньої мотивації. Дослідження було проведено із залученням 112 першокурсників Національного університету біоресурсів і природокористування України. Дизайн цього дослідження був кількісним за характером з використанням двох анкет як інструменту оцінювання. Учасники повинні були відповісти на всі питання анкети, надаючи інформацію про 1) свій досвід вивчення англійської мови та 2) власне ставлення до використання ігор при вивченні англійської мови для підвищення їхньої мотивації навчання. Отримані дані показали, що використання ігрових тренінгів основному сприяло покращенню мотивації студентів у вивченні англійської мови, і більшість студентів виявили позитивне ставлення до використання ігор у вивченні мови. Тільки 6\% студентів написали в описових питаннях, що вони не розвинули впевненості, і їх рівень інтересу до вивчення англійської мови залишався низьким під час навчальних сесій. Той факт, що переважна більшість студентів виявили позитивне ставлення до використання ігор при вивченні мови, свідчить про те, що цей метод може бути корисним при систематичному використанні протягом академічного року. Проте викладачі університетів повинні застосовувати різні підходи та стратегії для створення сприятливого навчального середовища в аудиторії, щоб студенти почувалися зацікавленими, мотивованими для досягнення своїх навчальних цілей.

Ключові слова: мотивація; вивчення англійської як другої мови; ігровий метод; тренінг.

\section{Цымбал Светлана}

Кандидат психологических наук, доцент, доцент кафедры английского языка для технических и агробиологических специальностей, Национальный университет биоресурсов и природоиспользования Украинь, г. Киев (Украина)

\section{ИГРОВЫЕ ТРЕНИНГИ В ПОВЫШЕНИИ МОТИВАЦИИ К ИЗУЧЕНИЮ АНГЛИЙСКОГО ЯЗЫКА}

Аннотация. Мотивация является одним из важнейших факторов в изучении языка, что придает студентам энтузиазма. В течение последних двадцати лет были разработаны методики обучения, направленные на повышение мотивации студентов с целью улучшения их речевых навыков. Использование игр в аудитории является одним из таких методов, дополняющих процесс обучения. В этой статье мы рассмотрели, как игровой метод преподавания английского языка специального употребления может повлиять на отношение студентов к языку и уровню их мотивации. Исследование было проведено с привлечением 112 первокурсников Национально- 
го университета биоресурсов и природопользования Украины. Дизайн этого исследования был количественным по характеру с использованием двух анкет как инструмента оценивания. Участники должны были ответить на все вопросы анкеты, предоставляя информацию о 1) своем опыте изучения английского языка и 2) своем отношении к использованию игр при изучении английского языка для повышения мотивации учения. Полученные данные показали, что использование игровых тренингов основном способствовало улучшению мотивации студентов в изучении английского языка, и большинство студентов обнаружили положительное отношение к использованию игр в изучении языка. Только 6\% студентов написали в описательных вопросах, они не развили уверенности и их уровень интереса к изучению английского языка оставался низким во время учебных сессий. Тот факт, что подавляющее большинство студентов обнаружили положительное отношение к использованию игр при изучении языка, свидетельствует о том, что этот метод может быть полезным при систематическом использовании в течение академического года. Однако преподаватели университетов должны применять различные подходы и стратегии для создания благоприятной учебной среды в аудитории, чтобы студенты чувствовали себя заинтересованными, мотивированными для достижения своих учебных целей.
Ключевые слова: мотивация; изучение английского как второго языка; игровой метод; тренинг.
Дата отримання статті: 09.07.2018 Дата рекомендації до друку: 14.07.2018 Дата оприлюднення: 02.08.2018 